\title{
Students' Grammatical Errors In Translating Indonesian Sentences Into English
}

\author{
${ }^{1}$ Imansyah, ${ }^{2}$ Fedrilla Rarasani \\ ${ }^{1}$ English Lecturer, Faculty of Business, Management, and Language, Mandalika University of \\ Education, Indonesia \\ ${ }^{2}$ English Student, Faculty of Business, Management, and Language, Mandalika University of \\ Education, Indonesia \\ Email; imansyah022@gmail
}

\begin{abstract}
The objectives of this research were to find out the types of students' grammatical error, the dominant type of students' grammatical error, and the causes of students' grammatical error in translating Indonesian sentences into English. It was a descriptive qualitative research. The subject of this research was the 11th grade Language students at SMAN 6 Mataram consisting of 29 students, and the samples of this research were the Indonesian sentences that had been translated into English and the answers of questionnaire by the 11th grade Language students at SMAN 6 Mataram. In collecting the data, translation test and questionnaire were employed.The result of translation test showed that students committed 100 errors in the form of omission, addition, missformation, and missordering. The most frequent error committed by students was omission (37 or 37\%). The second most frequently committed error was missformation (33 or 33\%), the error was addition (17 or 17\%), and the least was missordering (13 or 13\%). Based on the questionnaire, 38.7\% students' error was caused by interlingual (their mother tongue or source language).
\end{abstract}

Key words : grammatical errors, translating Indonesian sentences into English.

\section{INTRODUCTION}

In teaching foreign language, the learners often make errors when they use the foreign language as their target language. For that reason, it is important for teachers to be able to analyze the errors students commit as it gives the teacher evidence of the learner's competence in the foreign language (Johansson, 1975). James (2013) states that error is an observable phenomenon in FL/SL learning that has to be accounted for is second language learners stop short of native-like success in a number of areas 12 grammar". He suggests that language error as an unsuccessful bit of language. He also adds that language learners cannot correct their errors until they have additional knowledge on the topic. The language learners' error may occur because they do not have enough knowledge in the target language. According to Brown (2000: 218), error analysis is the study of students' error which can be observed, analyzed, and classified to reveal something of the system operating within the learners. Meanwhile, James (2013) states that error analysis is the process of determining the incidence, nature, causes, and consequences of unsuccessful language. In short, error analysis is the study to reveal the foreign language learners' errors in their target language production. According to Dulay, Burt and Krashen (1982) in James (2013: 106-110), there are four types of errors based on surface strategy taxonomy. They are omission error, addition error, miss formation error, and miss ordering error. These errors might occur because of some reasons, such as interlingual errors, intralingual errors, communication strategy-based errors, and induced errors (James (1998) in Sompong (2013)).

In Indonesia, English has been put as one of the subjects in its curriculum from primary level to university level. Even though the students have been learning English for years, in fact, most students find it difficult to be mastered. Consequently, errors occur when they produce written or spoken communication. One of the errors is in grammatical aspect. It can be occurred because Indonesian language (source language) and 
English (target language) have many differences, in terms of grammatical aspects. Brown (2000) defines errors as deviation of native grammar that reflects the interlingual competence of the learner.

The use of correct grammar in the target language production is necessary because without the grammar, the communication problem may occur in the target language production. Language without grammar would be chaotic and cause the same problem in communication, such as grammatical errors in writing and speaking (Batstone, 1994). For the reason, the use of correct grammar is important in English written and spoken production.

Grammatical errors would cause serious problems in English written and spoken production such as in translating Indonesian into English sentences. Newmark (1998) defines translation as an attempt to replace a written message and/or statement in one language by the same message and/or statement in another language. In translating activity, the translators must know almost perfectly about the language translated from and the language translated into to produce good translation. The use of grammar in the target language is one of the important aspects that is needed to produce good translation. Moreover, when the source and the target language have so many differences in grammatical aspect, the errors may occur in the result of translation because of this problem. Therefore, the English learners must have sufficient knowledge of English grammar to do translation from Indonesian sentences into English. Thus, the sufficiency of knowledge in English grammar will not be the cause of errors in their English sentences which have been translated from Indonesian sentences, and finally they will translate Indonesian sentences into English as the good translation. Based on the preliminary observation, most of the students stated that their grammatical errors were often caused by the differences of grammar rules between Indonesian and English, and also their understanding of English grammar rules. The grammatical errors can be problem in their English production. It is as stated by Batstone (1994) "language without grammar would be chaotic and cause the same problem in communication such as in grammatical errors in writing and speaking". Based on the problem above, the researchers were interested to conduct this research at SMAN 6 Mataram as the researchers were aware of the lack of grammatical competency of the students. Based on the preliminary observation, it was found that the students made grammatical errors frequently when they used the English either in spoken or in written form. The objectives of this research were to figure out the types, the dominant type, and the causes of students' grammatical error in translating Indonesian sentences into English made by the $11^{\text {th }}$ grade Language students at SMAN 6 Mataram.

\section{RESEARCH METHOD}

In conducting this research, the researchers used the descriptive qualitative design, which, according to Creswell (1994), is an inquiry process of understanding based on distinct methodological traditions of inquiry that explore a social or human problem. This research took place at SMAN 6 Mataram. It located at Peternakan street number 101 Selagalas, Mataram. This research was conducted in academic year 2019/2020, taking the $11^{\text {th }}$ grade Language students which consisted of 29 students as the subject, and the English sentences that had been translated from Indonesian sentences and the answers of questionnaire made by the $11^{\text {th }}$ grade Language students at SMAN 6 Mataram as the samples of this research. To answer the three questions, theories proposed by Dulay et.al and James were used. The researchers used translation test and questionnaire as the instruments to collect the data of students' grammatical errors and the data of causes of errors in translating Indonesian sentences into English. In analyzing the data, the researchers used some steps as follow.

1. Identify the students' grammatical errors.

2. Identify the the students' error causes.

3. Classify the students' grammatical errors.

4. Classify the students' error causes. 
5. Describe the students' grammatical errors. Describe the students' error causes.

\section{RESEARCH FINDINGS AND DISCUSSION \\ Research Findings}

In this section, the researchers will present the findings of types of errors committed by the students, the most dominant errors, and the causes of the errors.

\section{Types of Students' Error}

This finding was to answer the first research question "what are the types of students' grammatical error in translating Indonesian sentences into English made by students at SMAN 6 Mataram?". The researchers found 100 errors that made by the $11^{\text {th }}$ grade Language students in their English sentences that have been translated from Indonesian sentences. Their errors were divided into four types of error. Those were omission error, addition error, missformation error, and missordering error.

1) Translated by $S 1$.

In S1's translation, the researcher found 3 error (1 misformation error and 2 omission errors) from 3 sentences; those were sentence number 2, 4, and 7 as presented below.

The misformation error found in the sentence "dad came home last night when mom and I are cooking for dinner". Whereas the omission errors were found in sentence "mother usually get up early to prepare breakfast for her family" and "now I am reading a novel while my brother watching the horror movie".

2) Translated by $S 2$.

From the result of S2's translation test, the researcher found 3 error types, i.e. 1 misformation error, 1 addition error, and 1 omission error.

Misformation error was found in sentence "he don't like to eat fast food because it's not healthy", the addition error was found in the sentence "now I am reading a novel while my brother is watching a horror movies", and omission was found in the sentence "he always use the interesting teaching strategies so the students are enthusiastic to learn English".

3) Translated by S3.

From the 10 Indonesian sentences that had been translated into English by S3, the researcher found 5 error in 4 sentences. Those were 2 misordering error, 2 omission errors, and 1 misformation errors. The misordering error was found in sentence "did you go to beach Senggigi yesterday to practice your English?" and In addition, the misformation error was found in the sentence number 2 "dad came home last night when mom and I are cooking for dinner". To be 'are' should be replaced by 'were' because it was an activity in the past time and used the Past Continuous tense. So, dad came home last night when mom and I were cooking for dinner" is the correct sentence. Moreover, the omission error was in sentence number 7 "now I reading a novel while my brother watching the horror movie". The 'to be' should be added in this sentence. The to be 'am' for subject ' $I$ ' and 'is' for 'my brother' because the both clauses of this sentences should use the Present Continuous tense, then it would be "now I am reading a novel while my brother is watching the horror movie". The last, the misordering also found in sentence 10 "they will make cakes delicious, soft, and sweet tomorrow". In this sentence, the adjectives should be mention first from the noun 'cakes'. So, it could be 'they will make delicious, soft, and sweet cakes tomorrow. Based on the data above, S3 made 5 errors in 4 sentences; those were

4) Translated by $\mathrm{S} 4$.

The researcher found 3 error sentences that have been made by S4. Those were sentence number 6,7 , and 8 ; those were presented in the following.

In sentence 6 "have you finish your English homework?" showed the omission error. It can be seen by omitting the suffix 'ed' of verb 'finish', because the Simple Perfect tense uses the verb-3, then the suffix 'ed' must be added, so it would be "have you finished your English homework?". 
Meanwhile, in the sentence number 7 "now I am reading a novel while my brother is watching the horror movies" was found the addition error. It can be showed by adding the ' $\mathrm{s}$ ' in the word 'movie' that was not needed. It is caused by 'movie' was singular. So, it could be "now I am reading a novel while my brother is watching the horror movie". And then, the omission error was also found in sentence 8 "she always uses the interesting teaching strategies so the students enthusiastic to learn English". It can be seen by omitting the to be 'are' of subject 'students' that should be added. So, it would be "she always uses the interesting teaching strategies so the students are enthusiastic to learn English". From the data above, S4 made 3 errors in 3 sentences; those were 2 omission error and 1 addition error.

5) Translated by S5.

The researcher found 5 errors in 4 sentences that have been made by S5. Those were sentence number 1, 2, 7, and 8 . In the sentence 1 "did you go to beach Senggigi yesterday to practice your English?" was misordering error because the word ordered of 'beach' and 'Senggigi' was error. The correct one should be 'Senggigi beach', then the correct sentence would be "did you go to Senggigi beach yesterday to practice your English?". In addition, the misformation errors were showed in the sentence 2 "dad come home last night when mom and I was cooking for dinner". Those misformation errors could be defined by using the verb 'come' in the independent clause that should use 'came', and also in the dependent clause that used 'was' for the plural subject 'mom and I', where it should be changed to be 'were'. Those form that should be used because this sentence expressed the activities that were in the past time, so this sentence should use the Simple Past tense and Past Continuous tense, and the correct sentence should be changed to be "dad came home last night when mom and I were cooking for dinner". And then, the misformation was also found in the sentence 7 "I am reading a novel while my brother watches the horror movie now". It can be seen by the use of Simple Present tense in the dependent clause, because it should use Present Continuous tense. So, it could be corrected to be "I am reading a novel while my brother is watching the horror movie now". And the last, the omission error was found in the sentence number 8 "he always use the interesting teaching strategies so the students are enthusiastic to learn English". It was error because it did not add the suffix 's' to verb 'use' that was needed as the form of Simple Present tense for the third person, so it should be "he always uses the interesting teaching strategies so the students are enthusiastic to learn English". In short, S5 made 5 errors in 4 sentences; those were 1 misordering error, 2 misformation errors, 1 addition error, and 1 omission error.

6) Translated by $S 6$.

In the result of S6' translation test, the researcher found 4 errors in the 3 sentences. Those were sentence number 2 , 4 , and 9. Where in the sentence 2 "dad come home last night when mom and I are cooking for dinner" has 2 misformation errors that can be seen by using the verb-1 'come' and the to be 'are' in this sentence. It should be written by the past form 'Simple Past and Simple Past Continuous tenses'. So, it should be "dad came home last night when mom and I were cooking for dinner". In addition, in the sentence 4 "mother usually get up earlier to prepare breakfast for her family" was found an omission error, where the suffix ' $\mathrm{s}$ ' that must be added in the end of the verb 'get' for the subject in third person form. So, it should be corrected to be "mother usually gets up earlier to prepare breakfast for her family". And the sentence 9 "there will some new rules at my school next month" was omission error that showed by the omitting 'be' after the auxiliary verb 'will'. It should be added because this sentence is without main verb, So 'there will be some new rules at my school next month" is right. It could be concluded that S6 made 4 
errors in the 3 sentences. Those errors were 2 misformation errors and 2 omission errors.

7) Translated by S7.

The researcher found 3 errors of 1 sentences that have been made by $\mathrm{S} 7$. Those errors were only in sentence 7 "now I read a novel while my brother watches the horror movies". In this sentence have been identified 3 that consisted of 2 misformation error and 1 addition error. The misformation errors could be seen by the use of Simple Present tense in this sentence where it should use Present Continuous tense. Meanwhile, the addition error could be showed by the use of word 'movies' in plural form. The word 'movie' must be written without 's' or in singular form. So, this sentence could be fixed to be "now I am reading a novel while my brother is watching the horror movie". In short, S7 made 3 errors was only in sentence number 7 that consisted of 2 misformation errors and 1 addition error.

8) Translated by S8.

After analyzing the result of S8 translation, there were 4 error of 3 sentences have been found by the researcher. Those sentences were number 5, 7, and 9. The first error came from the sentence 5 "she have a lot of books in her private library". The error was misformation error because S8 used the wrong form of the auxiliary verb 'have' for the subject 'she', where it should use 'has'. So, the correct one must be "she has a lot of books in her private library". And then, in the sentence 7 "now I reading a novel while my brother watching the horror movie" had 2 omission errors because she omitted the to be of subject 'I' and my brother. The to be 'am' should be added for subject 'I', and to be 'is' for subject 'my brother' to make this sentence grammarly, so the correct one is "now I am reading a novel while my brother is watching the horror movie". The researcher also found the omission error in the sentence 9 "there will some new rule at my school next month" where the student $\mathrm{H}$ did not add 's' in the noun 'rule' that must be written as the plural form. So, it could be "there will some new rules at my school next month". In short, S8 made 4 errors in 3 sentences that consisted of 1 misformation error and 3 omission errors.

9) Translated by $S 9$.

There were 5 errors of 3 sentences that have been made by S9. Those were sentence number 3, 5, and 7 . . The misformation error was found in the sentence 3 "he don't like to eat fast food because it's not healthy". Where in this sentence was used the auxiliary 'do' because it should use 'does'. 'Does' should be used because the subject of this sentence is the third person 'he', so it would be "he doesn't like to eat fast food because it's not healthy". The misformation error also found in sentence 5 "she hev a lot of book in her private library" that can be seen from the use of auxiliary verb 'have' for the subject 'she', where it should 'has' because 'she' is the third person. Beside that, the omission error was also found in this sentence that characterized by the omitting 's' of 'book' that must be added because the 'book' should be written in plural form, then 'book' must be ended by 's', so "she has a lot of books in her private library" is the correct sentence. The last, the researcher also found 2 misformation error in the sentence 7 "I read a novel while my brother watches the horror movie now" that showed by using the Simple Present tense form of this sentence. It should use the Simple Continuous tense form because this sentence expressed the activities that aare being done in the present time. So, "I am reading a novel while my brother is watching the horror movie" is right. In brief, S9 made 5 errors in 3 sentences consisted of 4 misformation error and 1 omission error.

10) Translated by $S 10$.

S10 made 4 errors ( 2 addition error and 2 omission errors) from 2 sentences. Addition was found in "right now I am reading a novels while my brother is watching the horror movie". Omission error was found in "he always uses the 
interesting teaching strategy so the students are the enthusiastic for learn English" that can be showed by omitting the 's' of word 'strategy', and the 'ing' of word 'learn'. In addition, in this sentence also found the addition error that could be seen by the present of article 'the' before 'enthusiastic' where it was not needed to be written.

11) Translated by S11.

After the researcher analyzing the data of S11, there were 5 errors (1 misformation error, 3 omission errors, and 1 addition error) in 4 sentences. The first error is misformation, appeared in sentence " $d o$ you go to Senggigi beach yesterday to practice your English?". Omission error was found in "he doesn't like eat fast food because it not healthy", "right now I am read a novel while my brother is watch the horror movie".The last error, an addition error was found in sentence "she always the uses the interesting teaching strategies so the students are enthusiastic to learn English".

There were 3 errors ( 1 omission error, 1 addition error, and 1 misordering error) in 3 sentences that made by S12. Omission error was found in sentence "mother usually get up earlier to prepare breakfast for her family" Meanwhile, in sentence 7 "now I am reading a novel while my brother is watching a horror movies" was identified as the addition error. Misordering error was found in sentence "there will some rules new at my school next month".

12) Translated by S13.

There were 4 errors ( 1 misordering error, 2 omission errors, and 1 addition error) from 3 sentences. Sentence "he has a lot of books in his library private" was considered as misordering error. Sentence "now I reading a novel while my brother watching the horror movie" was identified as omission error. Addition error was found in sentence "there will some the new rules at my school next month".

13) Translated by S14.
There were 3 errors ( 1 misformation error and 2 misordering error) from 3 sentences that made by S14. In the sentence 1 "did you go to beach Senggigi yesterday to practice your English?" and "he always uses the teaching strategies interesting so the students are enthusiastic to learn English" were identified as misordering error. Misformation error was found in sentence "dad comes home last night when mom and I were cooking for dinner".

14) Translated by $S 15$.

From 10 sentences that have been translated by $S 15$, there were 5 errors (1 addition error and 4 omission errors) in 4 sentences. Addition appeared in sentence "mother usually gets up earlier to prepare breakfast for the her family". Omission appeared in sentences "now I reading a novel while my brother watching the horror movie", "he always use the interesting teaching strategies so the students are enthusiastic to learn English", and "there will some new rules at my school next month".

15) Translated by S16.

The researcher found 4 errors (2 misformation error, 1 addition error, and 1 misordering error) from 4 sentences that made by S16. Sentence "mother usually gets up earlier to prepare breakfast for his family" and "he have a lot of books in his private library" were categorized as misformation error. Addition was found in sentence "he always uses the interesting teaching strategies so the students are the enthusiastic to learn English. The last error was misordering in the sentence "they will make cakes delicious, soft, and sweet tomorrow.

16) Translated by $S 17$.

There were 3 errors ( 1 omission error and 2 addition errors) in 3 sentences that made by S17. Sentence "he has a lot of book in his private library" was classified as omission error, while sentence "now I am reading a novels while my brother is watching the horror movie" and "he always the uses the interesting teaching strategies 
so the students are enthusiastic to learn English" were identified as addition error.

17) Translated by S18.

The researcher found 3 errors (2 misformation error and 1 misordering error) in 3 sentences that made by S18.The misformation error was found in sentence "do you go to Senggigi beach yesterday to practice your English?" and "dad came home last night when mom and I are cooking for dinner". Misordering error was found in "have you finished your homework English?".

18) Translated by S19.

There were 2 errors (were misformation error and omission error) in 2 sentences that made by S19; Sentence "she have a lot of books in her private library" was considered as misformation, while "he always uses the interesting teaching strategies so the students enthusiastic to learn English" was considered as omission error.

19) Translated by $S 20$.

There were 3 errors of misformation from different 2 sentences that made by $\mathrm{S} 20$. Those were "dad come home last night when mom and I are cooking for dinner" and "he don't like to eat fast food because it's not healthy".

20) Translated by $S 21$.

From the result of $\mathrm{S} 21$ translation test, there were 3 errors (2 misordering error and 1 omission error) that found in 3 sentences by the researcher. Sentences "did you go to beach Senggigi to practice your English?" and "he always uses the strategies teaching interesting so the students are enthusiastic to learn English" were classified as misordering, and "have you finish your English homework?" was classified as omission.

21) Translated by $S 22$.

The researcher found 4 errors (2 omission errors, 1 misordering error, and 1 addition error) from 3 sentences made by $\mathrm{S} 22$. Omission error occurred in sentence "now $I$ reading a novel while my brother watching the horror movie". Meanwhile, in sentence "she always uses the teaching strategies interesting so the students are enthusiastic to learn English" was identified as misordering error and "there will some the new rules at my school next month" was categorized as addition error.

22) Translated by $S 23$.

After identifying the result of S23 translation test, there were 4 errors (1 misformation error, 1 omission error, 1 addition error, and 1 misordering error) of 4 sentences that have been found by the researcher. Those were "dad came home last night when mom and I was cooking for dinner" classified as misformation, "now $I$ reading a novel while my brother is watching the horror movie" classified as the omission error, "there will some the new rules at my school next month" classified as addition, and "they will make cakes delicious, soft, and sweet tomorrow" categorized as misordering error.

23) Translated by $\mathrm{S} 24$.

There were 4 errors ( 3 misformation errors and 1 omission error) of 3 sentences that made by S24; those number 2, 4, and 7 . They were "dad comes home last night when mom and I are cooking for dinner", "now I am reading a novel while my brother watches the horror movie", classified as misformation error, while "mother usually get up earlier to prepare breakfast for her family" classified as omission error.

24) Translated by $S 25$.

The researcher found 3 errors ( 2 omission errorr and 1 addition error) from 2 sentences that have been made by $\mathrm{S} 25$. Those were "have you finish your English?" have been identified 2 errors that categorized as omission errors. Those omission errors of this sentence can be seen by the suffix 'ed' was absent in end of verb 'finish' that must be written 'finished', and also the word 'homework' that was not written by the student $Y$. The word 'homework' should be present in this sentence because it was the translation of word 'PR'. Meanwhile, in sentence 7 ' now I am reading a novels while my brother is watching the horror movie" was error 
because the student $\mathrm{Y}$ wrote the word 'movies' as plural where it should be singular. So, the 's' was not needed to be added, then to make it right, this sentence must be changed to be "now I am reading a novel while my brother is watching the horror movie".

25) Translated by S26.

After identifying the result of S26 translation test, there were 4 misinformation errors in 3 sentences that found by the researcher. Those errors were " $d$ o you go to Senggigi beach yesterday to practice your English?", "dad comes home last night when mom and I are cooking for dinner", and "he have a lot of books in his private library

26) Translated by $S 27$.

There were 4 errors of 4 sentences that have been made by S27; Those could be found in sentence number 4, 7, 8, and 9 . The error was found in sentence 4 "mother usually get up earlier to prepare breakfast for her family" that characterized as omission error because the suffix ' $\mathrm{s}$ ' of verb 'get' was not added. In addition, the error was identified as misformation error in sentence 7 "right now I am reading a novel while my brother watched the horror movie". Moreover, in the sentence 8 "she always use the interesting teaching strategies so the students are enthusiastic for learning English" was characterized as omission error because in the verb 'use'. And the last one was found in sentence 9 "there will the some new rules at my school next month" as addition error because of "the".

\section{The Dominant Type of Students' Error}

This finding was to answer the second research question "what are the dominant type of students' grammatical error in translating Indonesian sentences into English made by students at SMAN 6 Mataram?". The percentage of error was calculated by this formula: omission error / addition error / missformation error / missordering error x 100 . Here will be presented the table of students' error percentage.
Table 2 The Dominant Errors Committed by

Students. The total error was $100=100 \%$.

\begin{tabular}{|l|l|l|l|}
\hline No. & \multicolumn{1}{|c}{ Error type } & \multicolumn{1}{c|}{ Number of each Error } & Error Percentage \\
\hline 1. & Omission Error & 37 of 100 & $37 \%$ of $100 \%$ \\
\hline 2. & Addition Error & 17 of 100 & $17 \%$ of $100 \%$ \\
\hline 3. & Misformation Error & 33 of 100 & $33 \%$ of $100 \%$ \\
\hline 4. & Misordering Error & 13 of 100 & $13 \%$ of $100 \%$ \\
\hline
\end{tabular}

From the table above, we can see that omission error appeared with 37 times (37\%) and made it the most dominant errors committed by the students. On the second most dominant error, misformation appeared 33 times (33\%), the next was addition with $17 \%$, and the least was misordering error with $13 \%$.

\section{The Causes of Students' Error}

This finding was to answer the last research question "what are the causes of students' grammatical error in translating Indonesian sentences into English made by students at SMAN 6 Mataram. The researchers found the total of error causes was 138 which were collected through their answers in the questionnaire. The formula that was used to count the percentage of students' error causes; interlingual / intralingual / communication strategy-based error / induced x 100. In the following can be seen the percentage of students' error causes by the table.

Table 3. The Causes of Errors Committed by Students.

\begin{tabular}{|c|l|l|l|}
\hline $\begin{array}{c}\text { No } \\
.\end{array}$ & Questions & \multicolumn{1}{|c|}{$\begin{array}{c}\text { Error } \\
\text { Causes }\end{array}$} & $\begin{array}{c}\text { Number of } \\
\text { Error }\end{array}$ \\
\hline 1. & $\begin{array}{l}\text { Do you } \\
\text { translate } \\
\text { the } \\
\text { Indonesian } \\
\text { sentences } \\
\text { into } \\
\text { English } \\
\text { word by } \\
\text { word? }\end{array}$ & $\begin{array}{l}\text { Interlingual } \\
\text { of } 138= \\
12,31 \%\end{array}$ \\
\hline 2. & $\begin{array}{l}\text { Do you } \\
\text { translate } \\
\text { the }\end{array}$ \\
$\begin{array}{l}\text { English } \\
\text { sentences } \\
\text { into } \\
\text { English by } \\
\text { transferrin } \\
\text { g your } \\
\text { knowledge }\end{array}$ & & 21 of $138=$ \\
& & $15,21 \%$ \\
\end{tabular}




\begin{tabular}{|c|c|c|c|}
\hline & $\begin{array}{l}\text { of } \\
\text { Indonesian } \\
\text { grammatic } \\
\text { al in your } \\
\text { translation } \\
?\end{array}$ & & \\
\hline 3. & $\begin{array}{l}\text { Do you get } \\
\text { difficulties } \\
\text { to use the } \\
\text { dictionary } \\
\text { in } \\
\text { selecting } \\
\text { the } \\
\text { equivalent } \\
\text { words in } \\
\text { Indonesian } \\
\text { and } \\
\text { English? }\end{array}$ & $\begin{array}{l}\text { Interlingual } \\
\text { error }\end{array}$ & $\begin{array}{l}15 \text { of } 138= \\
10,86 \%\end{array}$ \\
\hline 4. & $\begin{array}{l}\text { Do you } \\
\text { find } \\
\text { difficulties } \\
\text { in } \\
\text { understand } \\
\text { ing } \\
\text { English } \\
\text { grammar } \\
\text { usage? }\end{array}$ & $\begin{array}{l}\text { Intralingual } \\
\text { error }\end{array}$ & $\begin{array}{l}23 \text { of } 138= \\
16,7 \%\end{array}$ \\
\hline 5. & $\begin{array}{l}\text { Do you } \\
\text { understand } \\
\text { well about } \\
\text { English } \\
\text { grammar } \\
\text { that you } \\
\text { have } \\
\text { learned? }\end{array}$ & $\begin{array}{l}\text { Intralingual } \\
\text { error }\end{array}$ & $\begin{array}{l}24 \text { of } 138= \\
17,4 \%\end{array}$ \\
\hline 6. & $\begin{array}{l}\text { Do you } \\
\text { concern } \\
\text { the } \\
\text { English } \\
\text { grammar } \\
\text { usage } \\
\text { when you } \\
\text { make } \\
\text { English } \\
\text { sentences? }\end{array}$ & $\begin{array}{l}\text { Intralingual } \\
\text { error }\end{array}$ & $\begin{array}{l}5 \text { of } 138= \\
3,62 \%\end{array}$ \\
\hline 7. & $\begin{array}{l}\text { Do you } \\
\text { make a } \\
\text { new } \\
\text { concept of } \\
\text { English } \\
\end{array}$ & $\begin{array}{l}\text { Communica } \\
\text { tion } \\
\text { strategy- } \\
\text { based error }\end{array}$ & $\begin{array}{l}11 \text { of } 138= \\
7,97 \%\end{array}$ \\
\hline
\end{tabular}

\begin{tabular}{|c|c|c|c|}
\hline & $\begin{array}{l}\text { grammar } \\
\text { to } \\
\text { construct } \\
\text { your } \\
\text { English } \\
\text { sentences } \\
\text { when you } \\
\text { don't } \\
\text { know the } \\
\text { correct } \\
\text { one? }\end{array}$ & & \\
\hline 8. & $\begin{array}{l}\text { Does your } \\
\text { English } \\
\text { teacher tell } \\
\text { you about } \\
\text { the } \\
\text { mistakes } \\
\text { that you } \\
\text { made } \\
\text { when you } \\
\text { speak and } \\
\text { write in } \\
\text { English? }\end{array}$ & $\begin{array}{l}\text { Induced } \\
\text { error }\end{array}$ & $\begin{array}{l}8 \text { of } 138= \\
5,79 \%\end{array}$ \\
\hline 9. & $\begin{array}{l}\text { Does your } \\
\text { English } \\
\text { teacher } \\
\text { explain the } \\
\text { materials } \\
\text { clearly and } \\
\text { easy to be } \\
\text { understood } \\
\text { ? }\end{array}$ & $\begin{array}{l}\text { Induced } \\
\text { error }\end{array}$ & $\begin{array}{l}9 \text { of } 138= \\
6,52 \%\end{array}$ \\
\hline 10 . & $\begin{array}{l}\text { Does your } \\
\text { English } \\
\text { teacher } \\
\text { often give } \\
\text { you } \\
\text { English } \\
\text { writing } \\
\text { practice? }\end{array}$ & $\begin{array}{l}\text { Induced } \\
\text { error }\end{array}$ & $\begin{array}{l}5 \text { of } 138= \\
3,62 \%\end{array}$ \\
\hline
\end{tabular}

From the table above, it can be seen the highest percentage of students' error cause was influenced by interlingual error with 53 or $38,7 \%$, followed by intralingual error with 52 or $37,5 \%$, induced error with 22 or $15,9 \%$, and the lowest error cause appeared by communication strategy-based error with 11 or $7,9 \%$.

\section{DISCUSSION}




\section{Types of Students' Error}

According to Dulay, Burk, and Krashen (1982, in James 2013: 106-110), there are four types of errors based on surface strategy taxonomy. They are omission error, addition error, miss formation error, and miss ordering error. Related to this current research, these four types of errors were found committed by the students when they translated the text from Indonesian language into English. Omission, as Dulay, Burk, and Krashen state, is characterized by the absence of an item that must appear in a well-formed utterance". The omission error committed by students can be showed by omitting the important items in their English sentences such as to be 'is' and 'am', and also the suffix 'ing' or 's' of verbs that must be used, as in "mother usually get up early to prepare breakfast for her family" and "now I am reading a novel while my brother watching the horror movie".

The second was addition error. According to Dulay, Burt and Krashen, addition error is "the result of all-too-faithful use of certain rules". This error could be found in their English sentences that added the unnecessary item such as article 'the' and 's' that were in the singular noun. The proofs are "now I am reading a novel while my brother is watching a horror movies"

The third was missformation error. Dulay, Burk, and Krashen define "missformation errors are characterized by the use of wrong form of the morpheme or structure". The students' misformation error could be seen by the use of wrong form structure, where they used the wrong form of to be, verb, and also tenses of their English sentences. The examples are "dad came home last night when mom and I are cooking for dinner" and "he don't like to eat fast food because it's not healthy".

The fourth was missordering error. Missordering errors are characterized by the incorrect placements of a morpheme or word in an utterance (Dulay, Burk, and Krashen, 1982). In the result of their translation, the researchers found the students made misordering error by the permutation of word in their sentence such as the position of noun and adjective that were exchanged as in examples "did you go to beach Senggigi yesterday to practice your English?" and "they will make cakes delicious, soft, and sweet tomorrow".

\section{Dominant Type of Students' Error.}

In the findings section, the researchers have provided the percentage of error to know the dominant types of students' error that found in their English sentences. Based on the data on the finding section, the percentage of omission error was 37 errors of 100 or $37 \%$. It was the highest percentage of students' error type found by the researcher. This percentage showed that students were most likely to commit disappearance of the necessary item which should be present in their English sentences. Thus, we could conclude that the omission error was the dominant error types made by the eleventh grade Language students at SMAN 6 Mataram. Meanwhile, the percentage of misformation error was 33 of 100 or $33 \%$. It showed that the number of students who made misformation error was no more than omission error. So, the missformation error with $33 \%$ was the second dominant error type that which made by the eleventh grade Language students at SMAN 6 Mataram. The next one was addition error. It was 17 errors of 100 or $17 \%$. The percentage of addition error was less than missformation error, then the total number of addition error that made by the eleventh grade Language students at SMAN 6 Mataram was no more than the previous types. Therefore, it was the third dominant type that made by students. And the last one was missordering error. It was 13 errors of 100 0r 13\%. The percentage of this error was the lowest percentage of error type.

\section{Causes of the Error}

The first error causes of students that found by the researcher was interlingual error. According to James (2013), interlingual error is influenced by the native languages which interfere with target language learning". It was the highest percentage with 53 or $38.7 \%$. It was divided into 3 questions in the questionnaire, those consisted of 21 or $15,21 \%$ of students made error in their English sentences because they transferred the 
Indonesian grammatical in their English translation, 17 or $12,31 \%$ of students who made error because they translated the English sentences word by word, and 15 or $10,97 \%$ of students made error because they get difficulties to select the equivalent words in Indonesian and English when they use dictionary.

The second one was intralingual error. Jame states intralingual error as "These type of error is caused by the target language (TL) itself'. It was the second highest percentage with 52 or $37.5 \%$. It was divided into 3 questions in the questionnaire, those were 24 or $17,4 \%$ students made error because they don't understand well about English grammar that they have learned, 23 or $16,7 \%$ of students made errors because find difficulties in understanding English grammar usage, and 5 or 3,62\% students made error because they did not concern the English grammar usage when they make English sentences.

The third error cause was induced error. Jame says "this error is the result of being misled by the way in which the teachers give definitions, examples, explanations and arrange practice opportunities". It was the third highest percentage with 22 or $15.9 \%$. It was also designed into 3 questions in the questionnaire, those were 9 or $6,52 \%$ because the English teacher doesn't explain the materials clearly and easy to be understood, 8 or $5,79 \%$ because the teacher doesn't tell the students about the mistakes that they made when speak and write in English, and 5 or 3,62\% because the English teacher doesn't give the students English writing practice frequently.

Andersen, Sarah. 2014. Sentence Types and Functions. (p. 1). Jan Son State University: Writing Center.

Bassnett, Susan. 2002. Translation Studies. Third addition. New York: Routledge Taylor \& Francis Group.

Brown, H. Douglas. 2000. Principles Of Language Learning And Teaching. Fourth addition. San Francisco State University: Addison Wesley Longman, ICN Pearson Education Company.
The last error cause was communication strategy-based error. It is influenced by students' assumption and experience of concepts that use without concerning the different or equivalent forms. It was the lowest percentage with 11 or $7.9 \%$. This error was caused by the students make a new concept of English grammar to construct their English sentences when they don't know the correct one.

The result of this research was contrast with the result of Novita's research entitled "Grammatical errors im students' Translating Text By The Informatics Department Students In STEKOM Semarang" in 2018. This study showed that misformation was the highest errors with 96 errors or $54.8 \%$ of the whole errors. Meanwhile, intralingual factor was the most common sources of learner's errors with $75 \%$.

\section{CONCLUSION}

There were 100 errors made by 27 students which consisted of $37 \%$ omission error, $33 \%$ misformation error, $17 \%$ addition error, and $13 \%$ misordering error. From the percentage of each error above, it could be seen that the dominant type of students' error was omission error. Furthermore, this research found the highest percentage of students' error causes was found by $38,7 \%$ of interlingual error, $37,5 \%$ of intralingual error, $22 \%$ of induced error, and $11 \%$ of communication strategy-based error.

\section{REFERENCES}

Brown, H. Douglas. 2007. Principles of Language Learning And Teaching. Fifth addition. San Francisco State University: Pearson Education.

Cahyani, Sari, Bambang Wijaya and Zaenal Arifin. 2014. "Analysis OF STUDENTS' GRAMMATICAL ERRORS IN INDONESIAN-ENGLISH TRANSLATION". Pontianak: Tanjungpura University.

Creswell, John W. 2009. Research Design: Qualitative, Quantative, And Mixed 
Method Approaches. Third addition. Sage Publications.

Hogue, Ann. 2008. First Steps In Academic Writing Level. Second addition. (p. 10). United State of America: Pearson Educational.

Jakobson, R. 1971. "Word and Language On Linguistic Aspects Of Translation" Volume 10.1515 (p. 261).

James, Carl. 2013. Errors In Language Learning And Use. First addition. New York: Routledge.

Kusumaningtyas, Novita. 2018. "Grammatical Errors In students' Translating Text By THE INFORMATICS DEPARTMENT STUDENTS IN STEKOM Semarang". Semarang: School Of Electronics and Computer.

Leacock, Claudia, Martin Cordorow, Michael Gamon. 2010. Automated Grammatical Error Detection For Foreign Language Learners. University Of Toronto: Morgan \& Claypool.

MasteringBahasa.com. 2018. "11 Differences Between Indonesian and English Grammar", retrieved from https://masteringbahasa.com/differences -between-indonesian-and-englishgrammar/amp on Sunday, 15th December 2019 at 11.00 a.m.

Munday, Jeremy. 2008. Introducing Translation Studies Theory and Application. Second addition. America: Routledge.

Newmark, Peter. 1988. A text Book of Translation. New York: Pearson Education.

Rizky, Dwi Amalia, Ummi Khaerati Syam, and friends. 2018. "Errors In Indonesian Into English Translation Text Made By Students Of SMA 13 Pangkep". Makasar: Muhammadiah University.

Seaton, Anne YH New. 2007. Basic English Grammar. First addition. (p. 138). United State: Saddleback Educational Publishing.

Sompong, M. 2013. "Error Analysis". Volume 16 no. 2 . Thammasat University.

Tandikombong, Matius, Harianto Admowardoyo and Sukardi Weda. 2016.
"Grammatical Errors In The English Translation Made By The Students Of English Study Program Of UKI Toraja". State University Of Makasar: English Language Education Graduate Program. 